\title{
Deteriorating renal function in the asymptomatic patient: the importance of clinical examination!
}

\author{
Ahmed Seedat, ${ }^{1}$ Christopher Rowe, ${ }^{2}$ Bassam Fallouh ${ }^{2}$
}

${ }^{1}$ Department of General Medicine, Basildon and Thurrock University Hospitals NHS Foundation Trust, Basildon, UK ${ }^{2}$ Department of Renal Medicine, Basildon and Thurrock University Hospitals NHS Foundation Trust, Basildon, UK

\section{Correspondence to} Dr Ahmed Seedat, aseedat@doctors.org.uk
To cite: Seedat $A$, Rowe $C$ Fallouh B. BMJ Case Rep Published online: [please include Day Month Year] doi:10.1136/bcr-2013009125

\section{DESCRIPTION}

An 81-year-old gentleman was referred to the medical team by his general practitioner (GP) with a biochemically worsening renal function. Medical history included hypertension, chronic kidney disease and a 67 pack-year smoking history. Significantly, there was a history of angiotensinconverting enzyme inhibitor (ACE-i) use 3 months previously. The patient was otherwise asymptomatic. Admission bloods: $\mathrm{Na} 135 \mathrm{mmol} / \mathrm{l}, \quad \mathrm{K}$ $5.7 \mathrm{mmol} / \mathrm{l}$, urea $32.7 \mathrm{mmol} / \mathrm{l}$, creatine $358 \mu \mathrm{mol} / \mathrm{l}$ (baseline $150 \mu \mathrm{mol} / \mathrm{l}$ ), estimated-glomerular filtration rate (eGFR) $14 \mathrm{ml} / \mathrm{min}$. On examination, there was a large, non-tender pulsatile mass in the abdomen. Otherwise the systems examination was unremarkable. He proceeded to an ultrasound (figure 1) and a CT scan of the abdomen (figure 2) which showed an $11.8 \mathrm{~cm}$ diameter abdominal aortic aneurysm (AAA) just below the renal artery level. Both kidneys showed cortical scarring suggestive of chronic parenchymal disease; however, there was no evidence of hydronephrosis. The patient underwent semi-elective AAA repair as an inpatient. Postoperatively, there were no complications and the renal function showed improvement with an eGFR of 30 at discharge.

There have been few cases describing renal failure related to AAA. The association tends to be with the inflammatory abdominal aortic aneurysm (IAAA) subtype. The associated inflammatory process can cause urethral obstruction and subsequent obstructive uropathy. ${ }^{1}$ Current thinking tends to view IAAA as the extreme end of an inflammatory process leading to fibrosis, present to a variable degree in all AAA. ${ }^{1}$

The cause of deterioration in renal function remains unclear and may have been related to ACE-i use. Nevertheless, the identification of AAA was clinically important even if not directly responsible for the deterioration.

\section{Learning points}

- There have been few cases describing renal failure related to abdominal aortic aneurysm.

- The association tends to be with the inflammatory abdominal aortic aneurysm subtype. The associated inflammatory process can cause urethral obstruction and subsequent obstructive uropathy.

- This case highlights the importance of clinical examination, lateral thinking and open-mindedness when faced with an asymptomatic patient and abnormal blood results.

Figure 1 Abdominal ultrasound scan with a longitudinal view of the abdominal aortic aneurysm measuring $10.2 \mathrm{~cm}$ in anteroposterior diameter. The hyperechoic areas represent the thrombus. 

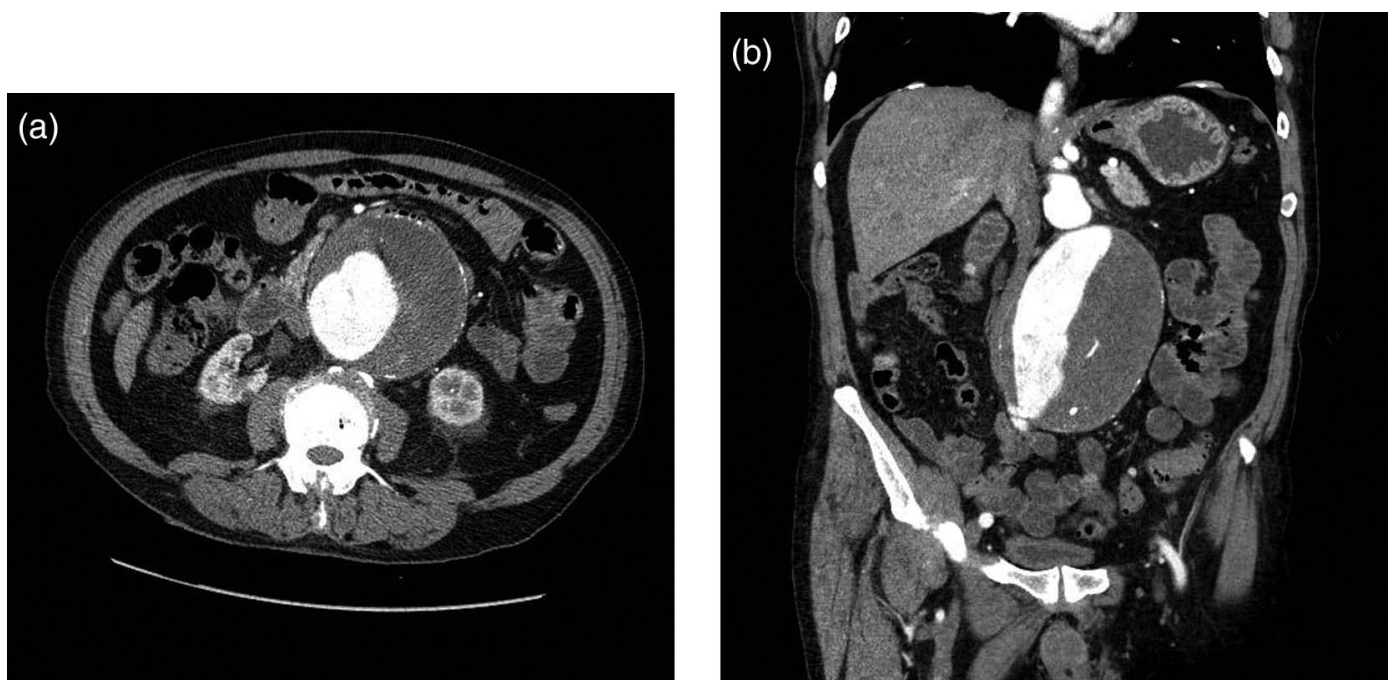

Figure 2 (A) Axial CT angiogram demonstrates a large infrarenal abdominal aortic aneurysm with eccentric thrombus and wall calcification. The kidneys are atrophic in keeping with the history of chronic kidney disease. (B) Coronal CT angiogram shows lateral displacement of the inferior vena cava by the large aortic aneurysm.

Contributors All authors were involved in the drafting of the article and in revising it critically for important intellectual content.

Competing interests None.

Patient consent Obtained.

Provenance and peer review Not commissioned; externally peer reviewed.

\section{REFERENCE}

1 Korzets $Z$, Witz $M$, Goldberg $E$, et al. The patient with asymptomatic advanced renal failure-obstructive uropathy caused by inflammatory abdominal aortic aneurysm. Nephrol Dial Transplant 1998;13:1835-7.

Copyright 2013 BMJ Publishing Group. All rights reserved. For permission to reuse any of this content visit http://group.bmj.com/group/rights-licensing/permissions.

BMJ Case Report Fellows may re-use this article for personal use and teaching without any further permission.

Become a Fellow of BMJ Case Reports today and you can:

- Submit as many cases as you like

- Enjoy fast sympathetic peer review and rapid publication of accepted articles

- Access all the published articles

- Re-use any of the published material for personal use and teaching without further permission

For information on Institutional Fellowships contact consortiasales@bmjgroup.com

Visit casereports.bmj.com for more articles like this and to become a Fellow 